\title{
Satu Triliun Rupiah Untuk Setiap Partai
}

Shohibul Anshor Siregar

Bayangkanlah, dengan cara apakah kelak Indonesia memastikan bahwa Satu T untuk Satu P tidak menjadi income korupsional para "pemilik" partai yang jumlahnya hanya beberapa orang itu? Alangkah senangnya mereka mendapatkan kesempatan menjadi "syetan modern" dalam proses demokratisasi itu.

Ada negara yang membiayai sepenuhnya partai politik seperti Uzbekistan. Ada pula yang sama sekali tak mensubsidi apa pun seperti Selandia Baru. Tetapi di antara kedua ufuk itu, ada variasi dalam persentase jumlah bantuan negara (dari standar tertentu yang disepakati) kepada partai. Menurut keterangan berbagai sumber, di Inggris, Italia, dan Australia, partai memeroleh bantuan $30 \%$ dari kebutuhan. Ada pun di Perancis, Denmark, dan Jepang, negara menyumbang 50 \%. Sedangkan Austria, Swedia, dan Meksiko sebesar $70 \%$.

Wacana peningkatan jumlah bantuan negara kepada partai menjadi Rp 1 triliun (Satu $T$ untuk Satu $P$ ) yang berkembang belakangan ini masih belum menemukan pengerucutan. Dimana-mana orang yang menolak cenderung hanya berbicara pantas atau tak pantas, dengan menggunakan ukuran kondisi sosial ekonomi rakyat saat ini. Jika kini Indonesia sangat perlu uang untuk membangun infrastruktur seperti pelabuhan, bendungan, irigasi, jalan, jembatan, gedung sekolah dan lain-lain, mengapa bukan itu yang menjadi prioritas pembelanjaan? Padahal karena perhitungan anggaran untuk sektor produktif seperti itulah pemerintahan Jokowi merasa amat yakin rasionalitas pemotongan subsidi harga BBM dilakukan dengan penuh resiko. Terasa juga sangat kontraproduktif dengan materi "jualan" Jokowi ke berbagai negara "we are waiting for you to come to Indonesia; we are waiting for your investations; this is your opportunity", dan lain sebagainya. Lagi pula cukup aneh juga bahwa di tengah kemiskinan yang hingga tak mampu menahan arus jumlah tenaga kerja tak berketerampilan ke berbagai negara dengan resiko perlakuan sangat buruk hingga ada yang harus kembali ke tanah air dalam peti mayat, malah mengalokasikan sejumlah besar uang kepada partai.

Tak jarang pula disertakan argumen-argumen penolakan skeptis seperti, apakah dengan pemberian bantuan sebesar itu korupsi politik akan serta-merta hilang dan kinerja partai akan otomatis lebih baik? Apakah seluruh partai yang secara umum kadar keburukannya benar-benar nyata tanpa pengecualian sama sekali akan diserahi uang sebanyak itu, padahal hampir pasti uang itu akan dikorupsikan oleh pemimpin partai?

Obsesi Kemandirian. Salah satu argumen pendukung Satu T untuk Satu P adalah kemandirian partai. Itu tentu sebuah isapan jempol belaka. Sedangkan tanpa bantuan sebesar itu pun Indonesia zaman Jokowi sudah memeragakan kekasaran kekuasaan terhadap masyarakat sipil melalui perlakuan buruknya yang telanjang terhadap partai, khususnya yang dialami oleh PPP dan Golkar. Orang begitu senang berlomba mendekati sumbu kekuasaan meski itu dengan mempermalukan sesama (internal) dalam satu partai. Konon lagi akan ada Satu T untuk Satu P? Jika tidak hati-hati, kebijakan Satu T untuk Satu P dapat sangat kontraproduktif terhadap demokrasi. 
Entah terkait atau tidak, tetapi jika gambaran Jokowi tentang kunci kemajuan Cina, yang dikemukakannya dalam kuliah umum di kampus UGM, yakni prasyarat bersatunya partai (partai-partai), tampaknya akan diperolehnya dengan begitu mudah melalui kebijakan Satu T untuk Satu P ini.

Esensi kuliah umum yang pernah disampaikan Jokowi di UCM dapat dibahasakan lain sebagai "permohonan untuk menjadi diktator dalam sebuah negara berlabel resmi demokrasi”. Tergantung kepada Indonesia akan memenuhi permohonan itu atau tidak, sepenuhnya atau separohnya. Kata Arbi Sanit, Jokowilah presiden Indonesia paling lemah sepanjang sejarah. Dengan cara apa Jokowi akan menjalankan mandatnya jika ia begitu lemah? SBY mampu berdialog dan akhirnya berdamai dengan hampir semua partai dengan ajakan yang disambut baik melalui bagi-bagi kekuasaan dengan tak hanya melalui distribusi jabatan menteri yang berjumlah besar, tetapi juga dengan pembentukan Sekretariat Gabungan Koalisi Partai (Setgab). Memang Jokowi sudah menambah jumlah kementerian, dan karena faktanya begitu tak berkuasa dalam mengisi pos-pos kementerian itu, maka keluhan awal (lemah) tidak tertutupi sama sekali hingga melanggar janjinya sendiri tentang kabinet ramping yang terkenal itu. Fakta Jokowi lemah akan paling mudah menjadi sub-ordinasi kekuasaan lain dengan saluran dan metode tertentu yang jarang dapat kelihatan oleh pengamatan dari luar. Kekuasaan itu memang tidak nyata senyata bangunan istana, bahkan seorang raja sekalipun terkadang selalu harus bertanya apakah dirinya yang sungguh-sungguh berkuasa atau, di manakah sesungguhnya kekuasaan itu.

Ada peramu kekuasaan di sekitar Jokowi, dan sejalan dengan pandangan Arbi Sanit, kelemahan Jokowi telah ditutupi oleh jaringan kekuasaan efektif yang mensubordinasikannya itu. Itu pulalah yang membuat penjelasan Arbi Sanit tidak terkonfirmasi di sini. Seorang lemah kok bisa sedahsyat itu mengutak-atik partai? Bagaimana ini bisa terjadi dan apa penjelasan yang masuk akal? Sebagai perbandingan, kata seorang aktivis demokrasi dari generasi 98, pada zaman Orde Baru Soeharto masih memerlukan pertimbangan etika demokrasi umum dan pandangan dunia untuk setiap langkahnya menata politik dalam negeri. Bahwa jika akan mengintervensi sebuah partai, katakanlah PDI yang kemudian harus pecah belah hingga salah satunya menjadi PDIP yang kini menjadi “milik" Megawati, lazimnya Orde Baru akan memilih modus operasi intelijen berbiaya sangat mahal untuk mengesankan dengan demokrasilah semua intervensi itu berlangung, maka pada zaman Jokowi tampaknya cukuplah hanya dengan mengandalkan seorang Yasonna $\mathrm{H}$ Laoly saja. Di tangan Yasonna H Laoly semua sudah bisa selesai kelihatannya, dengan hanya sedikit tambahan instrumen-instrumen remeh-temeh semisal tingkah kepremanan pada tingkat internal seperti yang menimpa Ngabalin baru-baru ini.

Kebijakan bipolar and segmentary process (politik belah bambu) pada zaman Belanda, Orde Lama, Orde Baru dan zaman Jokowi sebetulnya memiliki asas dan tujuan yang sama. Hanya saja ada yang sangat tak beretika. Boleh jadi hal ini salah satu hasil pembiasaan menikmati maki-maki pejabat yang sudah lazim menjadi asupan informasi politik seluruh rakyat Indonesia berkat hegemoni media mainstream yang sangat bertanggungjawab untuk degradasi ini, seperti yang dicontohkan selalu dengan gagah dan berani oleh Ahok, justru dari lokasi pusat operasi kekuasaan negara. Pada zaman Orde Lama bukan hanya politisi yang dipersulit dan bahkan dipenjarakan. Sisa 
personal Koes Plus yang masih hidup pasti masih dapat bercerita lancar untuk pengalaman dituduh sebagai penganut gagasan-gagasan kapitalistik dengan musik yang dikategorikan oleh kekuasaan sebagai genre ngak-ngik ngkok yang diklaim anti revolusi. Tetapi bayangkanlah, kini seorang vokalis dari sebuah kelompok paling kesohor pun sudah ikut-ikutan mencaci politisi (Haji Lulung) yang sedang berada di gelanggang pertarungan melawan kekuasaan (Ahok). Demokrasi memang sangat mahal, dan apa yang dinamai A tidak selalu harus dapat terbaca seperti apa adanya. Urusannya selalu tak sederhana.

Pertanggungjawaban. Regulasi kerap menjelma sebagai produk kesia-siaan belaka dalam demokratisasi Indonesia, hanya karena ia kerap menjadi sekadar fasilitasi bagi kehendak subjektif para penentu kekuasaan. Mendirikan KPK yang akhirnya harus dipreteli setelah terlebih dahulu dalam jangka waktu cukup lama diposisikan kurang lebih hanya sebagai juru bicara anti korupsi atau newsmaker wacana pemberantasan korupsi, adalah contoh terbaik yang kita miliki saat ini. Bayangkanlah, dengan cara apakah kelak Indonesia memastikan bahwa Satu T untuk Satu P tidak menjadi income korupsional para "pemilik" partai yang jumlahnya hanya beberapa orang itu? Alangkah senangnya mereka mendapatkan kesempatan menjadi "syetan modern" dalam proses demokratisasi itu.

Semua sudah sepakat bahwa dengan iyuran anggota sebuah partai tidak akan mampu melakukan pelestarian keberadaan, bahkan jika pun ditambah dengan subsidi yang didasarkan pada perolehan suara. Bangunan hegemoni pusat kepartaian itu sungguh berbiaya mahal, yang sesuai dengan rumus otonomi baru pasca revisi UU No 22 Tahun 1999, pengerdilan daerah terus-menerus harus dilakukan bahkan hingga uang korupsi di daerah pun harus diantarkan oleh para tersangkanya kepada pengendali hukum dan politik di pusat kekuasaan dengan cara dan adat tersendiri, sambil bersama-sama mencaci-maki daerah sebagai tempat raja-raja kecil bersinggasana korupsional. Juga tidak diperkenankan adanya orang atau badan usaha tertentu menyumbang melewati batas ketentuan yang ditetapkan. Jika ada pun negara atau kaki tangan negara (asing) ingin menentukan nasib Indonesia melalui campur tangan politiknya, itu pun selalu dilakukan secara tertutup dan seolah tak pernah terjadi sama sekali. Bukan pula pilihan yang baik jika partai diberi keleluasaan membuka badan usaha milik sendiri agar misalnya bisa sama-sama mengikuti tender pembangunan jaringan kretaapi sepanjang garis lintas darat Sumatera dan mereka berdamai saja membagi uang mundur untuk menyerahkan proyek itu kepada partai tertentu di antara peserta tender ecek-ecek yang sudah amat dilazimkan itu.

Lalu dengan cara apa sebuah partai dapat memenuhi fungsinya? Mungkin diperlukan melamar para penguasa ekonomi, atau para bandit besar yang nanti menjadi garda terdepan penyelamatan partai karena pengaruhnya dapat sangat diandalkan untuk memaksa suara tidak boleh lari kemana-mana, atau yang bukan suara pun dipaksa menjadi suara di bawah legitimasi penyelenggara pemilu yang menjadi instrumen kriminalisiasi demokrasi. Untuk kondisi ini diperlukanlah selalu pemantangan kejelasan jumlah penduduk dan jumlah Daftar Pemilih Tetap, agar di tengah rakyat tidak perlu ada orang yang tahu jika jumlah pemilih dapat lebih besar ketimbang jumlah penduduk, dan pemilunya tetap dianggap legitimated meski nanti harus lewat 
pintu Mahkamah Konstitusi yang juga sudah merencanakan peradilan seburuk yang mereka mau.

Karena kekuasaan adalah alibi terbaik di mata hukum, maka kebijakan Satu $T$ untuk Satu P kelak bisa mengulangi cerita buram tentang PKS dan ustaz LHI yang diopinikan sebagai koruptor paling berbahaya abad ini, padahal anak kecil pun tahu bahwa power tend to corrupt dan oleh karena itu more power pasti bermakna more corrupt. Satu T untuk Satu P bisa membuat semua “pemilik" partai menjadi orang kaya yang semakin mapan dengan kekayaannya, tetapi jika tak patuh kepada kekuasaan, atau tumbuh serius menjadi sebuah partai sungguhan yang tangguh, bisa mengantarkan para pentolannya berakhir di lembaga pemasyarakatan. Tentu satu sisi pastilah sangat senang menjelang akhir hayat menimang-nimang Satu $T$, sambil mempertegas pembiayaan untuk memperkokoh diri sebagai premus interpares kampungan di dunia modern. Tetapi pertanyaannya untuk apalah semua ini dilakukan? Ini bukan pertanyaan bodoh.

Akibat dimensi kebebasan dalam demokrasi yang tumbuh melampaui batas yang dianggap normal dengan didorong oleh asa pelampiasan dendam politik yang mengendap di alam bawah sadar selama berpuluh tahun, maka partai-partai yang merasa terancam oleh kebebasan bernuansa egalitarian itu pun memilih untuk menapaki kecenderungan baru menjadi kerajaan-kerajaan kecil berkedok demokrasi yang menscreening semua anggotanya agar seragam dalam kepatuhan naif. Menjadi hayalilah semangat memeroleh para kader dan legislator cerdas, mandiri, ideologis dan tangguh dalam iklim seperti ini. Kemandirian yang diangankan dari Satu T untuk Satu P akhirnya sangat adhock, dan negara pada gilirannya $100 \%$ akan mengendalikan keterpimpinan untuk bersama-sama merampas kebebasan dan rasionalitas, untuk selanjutnya hanya menyisakan orang-orang hipokrit di pentas politik dan kekuasaan. Mereka yang tersisa itu mungkin saja gemuk, tampan, cantik, pandai bertutur bahasa, dan kelihatan sehat-sehat, tetapi sesungguhnya adalah beban yang justru membuat negara dan bangsanya terpuruk.

Percepatlah keputusan pengalokasian Satu T untuk Satu P itu agar tatanan politik baru dapat dimulai. Tentukan dengan pasti Electoral Treshold dan Parliamentary Treshold di atas 7,5 \%, agar langsung mengemilinasi partai-partai yang tak serius. Tanpa perbaikan pemilu, dan jika akan tetap mempercayakannya kepada KPU model sekarang, Satu T untuk Satu P adalah kesia-siaan.

Tak dapat dibayangkan memang, tetapi dipikirkanlah pengawasan atas pembelanjaan partai politik yang diawali dengan konsep matang tentang alokasi dan distribusi transaparan hingga tak menjadi "makanan" empuk bagi "pemilik" partai. Korupsi politik yang begitu marak bisa dielemininasi. Anggota legislatif tak perlu memikirkan setoran apa pun ke partai, karena ia cukup memberi prestasi setinggi-tingginya hingga ketiga fungsi lembaga tempatnya bekerja (legislasi, budget dan pengawasan) terlaksana dengan sebaik-baiknya. Satu $T$ untuk satu $\mathrm{P}$ dapat memberi harapan bagi kemajuan demokrasi Indonesia, asalkan tak seperti tingkah blusuan kian kemari tanpa tindak lanjut yang menyisakan angan tak sampai selamanya. 
Shohibul Anshor Siregar Naskah ini pertamakali diterbitkan oleh Harian Waspada Medan, Senin, 23 Maret 2015, hlm B7 